\title{
National Cultures and Politeness Strategies in Intercultural Communication Among Japanese and American Characters in "The Last Samurai" Movie: A Cross-Cultural Pragmatic Analysis
}

Eka Nurilaila; Universitas PGRI Madiun

Sigit Ricahyono $\bowtie$; Universitas PGRI Madiun

Dwi Setyadi; Universitas PGRI Madiun

Samsul Arifin; Universitas PGRI Madiun

\begin{abstract}
The study which is descriptive qualitative in nature, aims to investigate preference of politeness strategies by American and Japanese characters in "The Last Samurai movie and explain it in terms the national culture. Results show that the order of preference by Americans is: 1) BoP (11/50\%), 2) PoP (7/31.8\%), 3) NeP (3/13.6\%), and 4) OfR (1/4.5\%). That by the Japanese is: 1) OfR (18/60\%), 2) BoR (6/20\%), 3). NeP (6/20\%), 4) PoP (0). American national culture and that of Japan which are different affect their preference of politeness strategies shown in "The Last Samurai" movie. In conclusion, language and culture affect each other. People coming from different language and culture communicate differently.
\end{abstract}

Keywords: National culture, politeness strategies, intercultural communication, japanese, american, cross-cultural pragmatics.

$\triangle$ ricahyono@yahoo.com

Citation: Nurilaila, E, Ricahyono, S., Setyadi, D., \& Arifin, S. (2020). National cultures and politeness strategies in intercultural communication among japanese and american characters in "The Last Samurai" movie: A cross-cultural pragmatic analysis. Social Sciences, Humanities and Education Journal (SHE Journal), 1(1), 10 - 17.

\section{(cc) BY-NC-SA}

Published by Universitas PGRI Madiun. This work is licensed under the Creative Commons AttributionNonCommercial-ShareAlike 4.0 International License. 


\section{INTRODUCTION}

Literature review shows that intercultural communication (IC) along with politeness strategies have become among favourite research interests among researchers. Such studies by Moon, Uskul and Weick (2019), Lee, Park, Imai \& Dolan (2012), Kiyama, Tamaoka, and Takiura (2012) are those investigating the interrelation between culture and language, politeness strategies, in particular. IC vitality in daily lives comes into reality as the world today is characterized by an ever growing number of contacts involving people coming from different linguistic and cultural backgrounds. Cultural dimensions ("National Culture Hofstede Insights," n.d.) consists of six dimensions. They can represent independent preferences for one state of affairs over another and accordingly they can distinguish countries. To put it in other words, cultural dimensions can show the interrelatedness among culture, language and nation. Politeness is defined as using communicative strategies to create and maintain social harmony. Yule (2010), "Politeness can be defined as showing awareness and consideration of another person's face." It means that politeness is showing how person's awareness and consideration to other when they do communication. The last Samurai is among famous movies. This movie was produced by Edward Zwick and released on December $5^{\text {th }}, 2003$. In the movie there are politeness strategies used by the characters coming from different languages and cultures, American and Japanese.

Comparing and contrasting language behaviors and explaining them with regards to culture under the umbrella of cross-cultural pragmatics is worth investigating as studies on this field of interest terminate in conflicting findings where some do support the East-West devide while some others do not. Goldenberg, Ginexi, Sigelman, \& Poppen (1999) examined whether cultural and gender differences in directness of communication are reflected in styles of refusing unwanted sexual advances found possible cultural differences in the meaning of direct refusals of sexual advances. Shearman, Dumlao \& Kagawa (2011) investigated a major conflict with parents crosscultural variations in family communication found Americans and Japanese were different. Oetzel et al. (2003) examined the effects of national culture, self-construals, and power distance on face concerns and facework behaviors during conflicts with parents and siblings. Among the findings is national culture affects language behaviors. Lee at al. (2012) investigated whether apologies and thanks are used differently when asking favors in the United States and Japan and examined whether their use makes a favor asking message less face-threatening. Among the findings are that more Japanese included apologies in their messages while more Americans used thanks and that Japanese considered apologies to reduce some face threats while Americans did not consider thanks to reduce face threats. Kavanagh (2016) investigated politeness strategies channeled through the medium of emoticons in American and Japanese online personal weblog comments. The findings is that although American and Japanese blog comment writers both utilized emoticons that helped to convey positive politeness strategies Japanese used them significantly more than Americans and thereby challenge the notion of Japanese as being a negative orientated culture. In contrast to those finding East-West devide, King \& Aono (2017) discussed the issue of tolerance of silence within university tutorials from a cross-cultural, comparative perspective between Japan and the UK and concluded that there was no significant difference in the length of 
silence as students from both groups could tolerate during tutorials. Likewise, Chen, He \& Hu, (2013) reported an empirical investigation of Chinese requests where Chinese requests may not be as direct as has been argued in the literature and thereby against the claim that East and West are fundamentally different in their respective politeness systems.

\section{METHOD}

The current study is exploratory in nature as it "is concerned with why phenomena occur and the forces and influences that drive their occurrence" (Ritchie and Lewis 2003: 28) and is qualitative as it focuses on understanding social phenomena from the perspective of the human participants in natural setting without any hypothesis approach (Ary et al., 2010). Data analysis procedures follow Miles et al. (2014) involving data condensation, data display and conclusion. Data collected are displayed in tables following the taxonomy of politeness strategies by Brown and Levinson (1987).

\section{RESULTS}

Realization of language behaviors in terms of politeness strategies performed by both American and Japanese characters when they are interacting is shown in table 1 . and table 2 . The comparison and contrast is presented in Table 3.

As can be seen from Table 1., in the dialogues among American characters, it is found 22 strategies in six settings. BoR is the most preferred politeness strategy, appearing 11 times and making up $50 \%$. PoP comes the second, used as many as 7 times and contributing $31.8 \%$. OfR becomes the least to occur as only one time to occur and to make up $4.5 \%$. NeP is the second least preferred strategy. It appears 3 times and contributes $13.6 \%$.
As Table 2. illustrates, there are 30 politeness strategies in 6 different settings by Japanese characters. Overall, OfR is the most favoured by the Japanese, which occurs 18 times and contributes $60 \%$. Bor and $\mathrm{NeP}$ are the second favourites. Respectively, they appear 6 times and contribute $20 \%$. Pop does not occur at all in the dialogues among Japanese.

As Table 3. shows, American and Japanese characters prefer differently in terms of politeness strategies they used. Broadly speaking, BoR is the most preferred by Americans. In contrast, it is OfR by Japanese occurring 18 times but only 1 times by Americans. While PoP comes out to be the second most favoured by Americans, it does not takes place at all among Japanese.

\section{Bald on Record (BoR)}

There are 11 dialogues involving the Americans and 6 dialogues of the Japanese in "The Last Samurai" movie which belong to BoR type. The American characters that use BoR strategies are,1 dialogue from $\mathrm{D}, 5$ dialogues from $\mathrm{A}, 2$ dialogues from J, 2 dialogues from $\mathrm{C}$, and 1 dilogues from I. The Japanese characters that use BoR strategies are 1 dialogue from $E$, 1 dialogue from $F$, and 4 dialogues from $\mathrm{H}$. "Just hear what the man has to say..." You insolent swine! Answer! You, speak!. BoR politeness strategies is higher in frequency used by the American people than Japanese. Most of the BoR dialogues above are produced by Algren Nathan.

\section{Positive Politeness (PoP)}

There are dialogues of the American but none dialogue found from Japanese in "The Last Samurai " movie which belong to the PoP type. Those are spoken by some characters from American and Japanese people. The American characters that use PoP strategies are, 2 dialogues from $\mathrm{C}, 4$ dialogues from $\mathrm{A}$, and 1 dialogue from $\mathrm{J}$. In contrast, there is no PoP strategies used by Japanese people in "The Last Samurai " movie. 
Table 1. Politeness strategies by American characters in "The Last Samurai" movie.

\begin{tabular}{llcccccc}
\hline \multirow{2}{*}{ No. Setting } & \multicolumn{3}{c}{ Types of politeness strategies } & \multicolumn{2}{c}{ Total } \\
\cline { 3 - 7 } & & BoR & PoP & NeP & OfR & N & $\%$ \\
\hline $\mathbf{1}$ & Restaurant & 2 & 1 & 0 & 0 & 3 & $13.6 \%$ \\
\hline $\mathbf{2}$ & Village & 2 & 1 & 0 & 0 & 3 & $13.6 \%$ \\
\hline $\mathbf{3}$ & House & 3 & 1 & 1 & 0 & 5 & $22.7 \%$ \\
\hline $\mathbf{4}$ & Imperial palace & 1 & 0 & 2 & 0 & 3 & $13.6 \%$ \\
\hline $\mathbf{5}$ & Public & 1 & 1 & 0 & 1 & 3 & $13.6 \%$ \\
\hline $\mathbf{6}$ & Battlefield & 2 & 3 & 0 & 0 & 5 & $22.7 \%$ \\
\hline Total N & 11 & 7 & 3 & 1 & \multirow{2}{*}{22} & \multirow{2}{*}{$100 \%$} \\
\hline Total $\%$ & 50.0 & 31.8 & 13.6 & 4.5 & & \\
\hline
\end{tabular}

BoR: Bald on record

PoP : Positive politeness

$\mathrm{NeP}$ : Negative politeness

OfR : Off record

Table 2 Politeness strategies by Japanese characters in "The Last Samurai" movie.

No. Setting Types of politeness strategies

Total

\begin{tabular}{llcccccc}
\hline $\mathbf{1}$ & Restaurant & 0 & 0 & 0 & 0 & 0 & $0 \%$ \\
\hline $\mathbf{2}$ & Village & 2 & 0 & 1 & 2 & 5 & $16,7 \%$ \\
\hline $\mathbf{3}$ & House & 0 & 0 & 2 & 7 & 9 & $30 \%$ \\
\hline $\mathbf{4}$ & Imperial palace & 1 & 0 & 3 & 6 & 10 & $33,3 \%$ \\
\hline $\mathbf{5}$ & Public & 0 & 0 & 0 & 0 & 0 & $0 \%$ \\
\cline { 1 - 5 } $\mathbf{6}$ & Battlefield & 3 & 0 & 0 & 3 & 6 & $20 \%$ \\
\cline { 1 - 5 } Total N & 6 & 0 & 6 & 18 & \multirow{2}{*}{30} & \multirow{2}{*}{$100 \%$}
\end{tabular}

BoR: Bald on record

PoP : Positive politeness

$\mathrm{NeP}$ : Negative politeness

OfR : Off record

Table 3. Comparison and contrast on the politeness strategies by Japanese and American characters in "The Last Samurai" movie.

\begin{tabular}{|c|c|c|c|c|c|}
\hline \multirow{2}{*}{$\begin{array}{l}\text { Frequency of } \\
\text { Occurrence }\end{array}$} & \multicolumn{4}{|c|}{ Politeness Strategies } & \multirow{2}{*}{$\begin{array}{l}\text { Characters } \\
\text { by Nation }\end{array}$} \\
\hline & BoR & PoP & $\mathrm{NeP}$ & OfR & \\
\hline $\mathrm{N}$ & 11 & 7 & 3 & 1 & American \\
\hline$\%$ & 50,0 & 31,8 & 13,6 & 4,5 & \\
\hline $\mathrm{N}$ & 6 & 0 & 6 & 18 & Japanese \\
\hline$\%$ & 20 & 0 & 20 & 60 & \\
\hline
\end{tabular}

BoR: Bald on record

PoP : Positive politeness

$\mathrm{NeP}$ : Negative politeness

OfR : Off record 
"Nathan, I'd like you to meet Mr. Omura, from Japan, and his associates, whose names I've given up trying to pronounce..." Sit down. Sit down... American People such as C (Bagley), A (Algren Nathan, and J (Graham) used $\mathrm{PoP}$ to the speaker, but there is no PoP dialogues from the Japanese.

\section{Negative Politeness (NeP)}

It is found 3 dialogues of American and 6 dialogues by Japanese in "The Last Samurai" movie which belong to negative politeness strategies. The American characters that produce $\mathrm{NeP}$ are:, A (Algren Nathan) produced 2 dialogues and a dialogues from I (Ambassador Swanbeck). While, the those Japanese that produce $\mathrm{NeP}$ are: $\mathrm{B}$ (Katsumoto) produces 4 dialogues, $\mathrm{H}$ (Omura) produces 1 dialogues and 1 dialogues from $G$ (Taka).

"With all due respect, sir, our President's patience is wearing thin. Perhaps there is someone else we should be speaking to."

"If I am no use, then I will happily end my life."

Both American and Japanese utter $\mathrm{NeP}$ strategies to communicate with other people. However, more NeP strategies are produced by Japanese that is 6 dialogues. While those by Americans are 3 dialogues of NeP strategy.

\section{Off Record (OfR)}

It is found 1 dialogue by Americans and 18 dialogues by Japanese in "The Last Samurai" movie which belong to OfR strategies. The American character that produces the strategy is A (Algren Nathan), 1 dialogue. While, the Japanese that produce such strategy are:, B (Katsumoto) produces 10 dialogues, G (Taka) produces 2 dialogues, 4 dialogues produced by $\mathrm{H}$ ( Omura), 1 dialogue produced by $\mathrm{E}$ (Ujio) and 1 dialogue produced by K (Emperor).

"Mr. Graham, I need a drink."

"Many of our customs seem strange to you. The same is true of yours. For example, not to introduce yourself is considered extremely rude, even among enemies"

Japanese characters produce significantly more OfR than Americans.

\section{DISCUSSION}

The current study argues that language and culture are interrelated. Culture affects the way people use language. In summary, the preferences of politeness strategies dialogues in "The Last Samurai" movie by Americans are: 1) BoP $(11 / 50 \%), 2)$ PoP $(7 / 31.8 \%), 3)$ $\mathrm{NeP}(3 / 13.6 \%)$, and 4) OfR (1/4.5\%). Those by Japanese are: 1) OfR (18/60\%), 2) BoR 6/20\%), 3) $\mathrm{NeP}$ $(6 / 20 \%)$, and 4) PoP (0). American and Japanese characters prefer differently in terms of politeness strategies they used. Broadly speaking, BoR is the most preferred by Americans. In contrast, it is OfR by Japanese occurring 18 times but only 1 times by Americans. While PoP comes out to be the second most favoured by Americans, it does not takes place at all among Japanese. Such difference is made possible because of the linguistic and cultural backgrounds of the Japanese and Americans. This affirms the tight bond between language and culture. The results support the studies by Goldenberg et al (1999), Sherman et al (2011), Oetzel et al (2003), Lee et al (2012), Kavanangh (2016), Fukushima (1996), and, Liao \& Bresnahan (1996) emphasizing that language and culture affect each other and people coming from different language and cultural background communicate differently. This study is not in line with those by Chen et al (2013), King \& Aono (2017) confirming that "East \& West" do not differ in language behaviors.

\section{CONCLUSION}

The preferences of politeness strategies dialogues in "The Last Samurai" movie by Americans are: 1) BoP (11/50\%), 2) PoP (7/31.8\%),3) NeP (3/13.6\%), and 
4) OfR (1/4.5\%). Those by Japanese are: 1) OfR $(18 / 60 \%), 2)$ BoR 6/20\%), 3) NeP (6/20\%), and 4) PoP (0). This study, therefore, argues that language and culture are interrelated. They affect each other. This study affirms that the "East-West" devide does exist.

\section{REFERENCES}

Aijmer, Karin. (2006). Pragmatic Markes in Contrast. Netherlands: Elsevier.

Andersen, Gisle. (2001). Pragmatic Markers and Sociolinguistic Variation. Amsterdam: John Benjamins Publishing Company.

Ary, Donald et al. (2010). Introduction to Research in Education. USA: Wadsworth.

Brown, Penelope \& Levinson, Stephen C. (1987). Politeness Some Universal in language Usage. Cambridge. Cambridge University Press.

Chen, R., He, L., \& Hu, C. (2013). Chinese requests: In comparison to American and Japanese requests and with reference to the "EastWest divide." Journal of Pragmatics, 55, 140-161. https://doi.org/10.1016/j.prag ma.2013.05.012

Creswell, John W. (2009). Qualitative Inquary \& Research Design. Thousand Oaks: Sage Publication.

Dey, Ian. (1993). Qualitative data analysis: A user-friendly guide for social scientists. London: Routledge.

Eckert, Penelope \& McConnell-Ginet, Sally. (2003). Language and Gender. New York: Cambridge University Press.

Fukushima, S. (1996). Request strategies in British English and Japanese. Language Sciences, 18(3-4), 671-688. https://doi.org/10.1016/S03880001(96)00041-1

Goldenberg, J. L., Ginexi, E. M., Sigelman, C. K., \& Poppen, P. J. (1999). Just
Say No: Japanese and American Styles of Refusing Unwanted Sexual Advances1. Journal of Applied Social Psychology, 29(5), 889-902. https://doi.org/10.1111/j.15591816.1999.tb00130.x

Gray, Paul S. (2007). The Research Imagination. Cambridge: Cambridge University Press.

Griffiths, Patrick. (2006). An Introduction to English Semantics and Pragmatics. Edinburgh: Edinburgh University Press.

Hancock, Beverley. (2009). An Introduction to Qualitative Research. Nottingham: Copyright of the NIHR RDS EM/YH

Holmes, Janet \& Meyerhoff, Miriam. (2003). The Handbook of Language and Gender. UK: Blackwell Publishing.

Holmes, Janet. (2001). Introduction to Sociolinguistics. Edinburgh Gate: Pearson Education Limited.

Horn, Laurence R. \& Ward, Gregory. (2006). The Handbook of Pragmatics. UK: Blackwell Publishing.

Hughes, Marnie. (2007). History Goes to the Movie. USA: Routledge.

Hymes, Dell. (1996). Ethnography, Linguistics, Narrative Inequality. USA: Taylor and Francis

Karsberg, Henrik. (2012). Politeness strategies - a theoretical framework. Engeleska: Uppsats Grundniva

Kavanagh, B. (2016). Emoticons as a medium for channeling politeness within American and Japanese online blogging communities. Language \& Communication, 48, 53-65. https://doi.org/10.1016/j.langc om.2016.03.003

Kechkes, Istvan \& Horn, Laurence R. (2007). Explorations in Pragmatics. Berlin: Mouton de Gruyter

King, J., \& Aono, A. (2017). Talk, silence and anxiety during one-to-one 
tutorials: A cross-cultural comparative study of Japan and UK undergraduates' tolerance of silence. Asia Pacific Education Review, 18(4), 489-499. https://doi.org/10.1007/s12564 -017-9503-8

Kiyama, S., Tamaoka, K., \& Takiura, M. (2012). Applicability of Brown and Levinson's Politeness Theory to a Non-Western Culture. SAGE Open, 2(4), 215824401247011.

https://doi.org/10.1177/21582 44012470116

Lee, H. E., Park, H. S., Imai, T., \& Dolan, D. (2012). Cultural Differences Between Japan and the United States in Uses of "Apology" and "Thank You" in Favor Asking Messages. Journal of Language and Social Psychology, 31(3), 263-289.

https://doi.org/10.1177/02619 27X12446595

Liao, C., \& Bresnahan, M. I. (1996). A contrastive pragmatic study on American english and mandarin refusal strategies. Language Sciences, 18(3-4), 703-727. https://doi.org/10.1016/S03880001(96)00043-5

Mey, Jacob L. (2001). Pragmatics: An Introduction. UK: Blackwell Publishing.

Meyerhoff, Miriam. (2006). Introducing Sociolinguistics. New York: Routledge.

Miles, M \& Huberman, A. (2014). Qualitative Data Analysis. Thousand Oaks: Sage Publication.

Moon, C., Uskul, A. K., \& Weick, M. (2019). Cultural differences in politeness as a function of status relations: Comparing South Korean and British communicators. Journal of Theoretical Social Psychology, $3(3)$, 137-145. https://doi.org/10.1002/jts5.40

National Culture - Hofstede Insights. (n.d.). Retrieved January 14, 2020, from https://www.hofstedeinsights.com/models/nationalculture/

Oetzel, J., Ting-Toomey, S., ChewSanchez, M. I., Harris, R., Wilcox, R., \& Stumpf, S. (2003). Face and Facework in Conflicts With Parents and Siblings: A CrossCultural Comparison of Germans, Japanese, Mexicans, and U.S. Americans. Journal of Family Communication, 3(2), 67-93. https://doi.org/10.1207/s15327 698jfc0302_01

Ritchie, Jane \& Lewis, Jane. (2003). Qualitative Research Practice: A Guide for Social Science Students and Researchers. Great Britain: The Cromwell Press Ltd.

Shearman, S. M., Dumlao, R., \& Kagawa, N. (2011). Cultural variations in accounts by American and Japanese young adults: Recalling a major conflict with parents. Journal of Family Communication, 11(2), 105-125. https://doi.org/10.1080/15267 431.2011.554499

Wardhaugh, Ronald. (2006). An Introduction to Sociolinguistics. UK: Blackwell Publishing.

Watts, Richard J. (2003). Politeness. Cambridge: Cambridge University Press.

Yin, Robert K. (2011). Qualitative Research From Start to Finish. New York: Guilford Press.

YouTube, (2015). The Last Samurai Full Movie. Retrieved 30 October 2015, from https://www.youtube.com/watc $\mathrm{h} ? \mathrm{v}=\mathrm{FUqNV} 9 \mathrm{~d} 42 \mathrm{n} 8$

Yule, George. (1996). Pragmatics. New York: Oxford University Press.

Yule, George. (2006). The Study of Language. Cambridge: Cambridge University Press.

Yule, George. (2010). The Study of Language. Cambridge: Cambridge University Press. 
Zhu, Y., \& Bresnahan, M. J. (2018). Collective Face, Politeness Strategies, and Discomfort: Communication of American Domestic Students and Chinese
International Students. Journal of Intercultural Communication Research, 47(2), 141-159. https://doi.org/10.1080/17475 759.2018.1438304. 